\title{
The Role of Local NGOs in Promoting Primary Education: Evidence from Six Local NGOs in Sidama Zone, SNNPRS, Ethiopia
}

\author{
Biniyam Belachew Lemma \\ (MA in Development Management), Executive Director
}

\begin{abstract}
Education is among the determining factors of a country's development. Nothing can go right if education goes wrong. One cannot imagine about development when the actors of development are illiterate. In connection to this, in Ethiopia, a considerable attention and priority has been given to education in general and that of primary education in particular. In this regard, NGOs are playing important role in promoting the country's development. These motivated the researcher to assess the role of six local NGOs in promoting primary education in Sidama Zone. To examine the role of local NGOs in primary education promotion, both qualitative and quantitative research methods were employed. A total of 201 student respondents were systematically selected from 10,632 target population to conduct the questionnaires interviews. Primary data was collected by using questionnaire, interview, field observations and FGDs. The information obtained from these sampled local NGOs indicated that their involvement has brought different benefits to the target community like quality education service provision, improved the low awareness of community to send children to school, fulfilled the material needs of children in general and girls in particular, supplying different educational materials and teaching older children with vocational skills training in order to enrich students' future career. Above all, the educational project implemented by these local NGOs benefited older children beyond the conventional primary school age that they had no access to primary education before project intervention by the local NGOs. On contrary, the research reveals some important issues to be improved like lower level of community participation at identification and evaluation stages, challenges in sustaining vocational skills training and NGOs priority in targeting their projects in nearby districts. In relation to challenges, there are many challenges faced during the project intervention. Among which, lower level of capacity at grassroots level officials to support project implementation process, shortage of qualified teachers, high staff turnover in district education office and new Civil Society Organizations Proclamation on budget utilization. In addition to this, delay in starting the project after agreement signed and timely reporting problem were raised as challenges from district education office. It is concluded that, the intervention made by these local NGOs increased access, improved quality and ensured gender equity of education service provision. As the result, participation of students in general and that of girls in particular in those districts are improved after the intervention of education projects. In general, the community should participate at project identification and evaluation stages to ensure project sustainability and vocational skills training should be institutionalized and run by schools.
\end{abstract}

Keywords: Local NGOs, Primary Education, Projects, Role, Sidama

DOI: $10.7176 / \mathrm{JESD} / 12-17-04$

Publication date:September $30^{\text {th }} 2021$

\subsection{BACKGROUND OF THE STUDY}

Nongovernmental organizations (NGOs) are organizations which are founded by different interested person or group with the predetermined vision in order to address problems of specific target areas. They are an extremely diverse group of organizations which play different roles and take very different shapes and forms within and across different country contexts. The term NGO began to appear following the founding of the United Nations (UN) in 1945 to distinguish the concept of private organizations from governmental organizations (Ismail, 2012:751). The emergences of NGOs are not recent phenomenon in Africa as well. Their recorded of history includes the churches and missionary societies which not only existed throughout the colonial era and achieved their strengths and legitimacy through activism in such areas as human rights, but also progressively expanded in scope of activities to include women's groups, environmental protection, agricultural production, education, health and issues related to poverty alleviation (MDG report, 2011:25-26).

Primary education is both transformative and empowering. Beyond this intrinsic importance, it is also indispensable for the enjoyment of other human rights and is a means for accessing broader social, economic, political and cultural benefits (UNDG, 2010:6). Education contributes to building more just societies through reducing poverty and inequalities. No country has ever climbed the human development ladder without steady investment in education. Primary education is a powerful driver for the realization of all the Millennium Development Goals (MDGs) and for sustainable development more broadly (UNDG, 2010:6).

There are 960 primary schools in Sidama zone of which 106 primary schools are constructed and run by 
NGOs. The total number of students getting service from the schools are 1,074,369; of which, 81,365 are addressed by NGOs support (DoE, 2014:11). The current Ethiopian Government is also promoting NGO's intervention and foreign assistance to education by its Education and Training Policy and considered NGO involvement as one of the strategies in increasing access, improving quality and ensuring equity in education (MOE, 2002:22). As a result of that, there are many multilateral, bilateral and non-governmental organizations engaged in improvement of primary education in different regional states of Ethiopia. The aim of this study is assessing the contribution, practices and problems of NGOs in implementing primary education projects in Sidama Zone. The study emphasized on the assessment of the role of 6 local NGOs in attaining the below mentioned objectives and tries to suggest relevant recommendations that would help address the primary education promotion program by local NGOs in the Zone.

\subsection{STATEMENT OF THE PROBLEM}

According to the 2007 census, population of SNNPR is over 17 million in the year 2014 (CSA, 2007:24). The region is divided in to 14 zones, 4 special districts and twenty two Town Administrations. Out of 14 zones of the region, Sidama is the most populous and one of the densely populated zones. Its population is projected to be 3.4 million (CSA, 2007:24). The education coverage of the region was at its lowest stage before the implementation of Education and Training Policy (ETP) in the year 2002. It was below 19 percent. The condition for girls and rural children were the worst. In addition to this, large number of children discontinued their education before completing even the first cycle of primary education (SNNPRS, Education Bureau Annual Report, 2014:23-54).

Moreover, the prior studies conducted and mentioned below on the role of NGOs in Ethiopia and other developing countries were focused more on the role of NGOs in poverty reduction. For instance, Belshaw \& Coyle (2001), Emoke (2009) and also Fraser (2013) conducted study on the role of NGOs in food security, income generation, access to social services, orphan and street children care and environmental protection. However, less attention was given to the role of local NGOs in the development of primary education by the prior studies.

Although the involvement of these NGOs in education sector is highly recognized, most of the research output didn't clearly indicate the role of local NGOs in harnessing the quality and coverage of primary education. Even though some NGOs are working in the areas of education in Sidama zone and SNNPR, primary education enhancement by NGOs in Sidama zone is least investigated phenomena.

After the implementation of Education and Training Policy and Education Sector Development Programs in 2002, the SNNPRS's primary education enrollment in general and that of Sidama Zone in particular has shown significant improvement. The region achieved such improvement not only through the sole efforts of the government but also there are many NGOs and external donor agencies, which have played significant role to it. This study aims at assessing the role of local NGOs in supplementing the effort of the government in creating access to primary education in the region in general and Sidama zone in particular. There is a dearth of studies conduct in these local NGOs to investigate the contribution, practices and problems of these NGOs in implementing primary education projects in study area.

\subsection{RESEARCH OBJECTIVES:}

The overall objective of this study is to examine the role of local NGOs in primary education promotion projects in Sidama Zone and to assess whether the development intervention made by them were in line with the needs of the communities or not.

The Specific objectives of this study are the followings:

- To assess the major contribution of the local NGOs in terms of increasing access, improving quality and ensuring gender equity of primary education in the Zone.

- To assess the level of participation of the government, parents and local community in project identification, design, planning, implementation and monitoring and evaluation of the local NGOs education projects.

- To investigate the strategy of the local NGOs designed to make the education projects sustainable when the project phases out.

- To find out main challenges and opportunities that is encountered during the proper implementation of the local NGOs education projects in the study area.

\subsection{REVIEW OF RELATED LITERATURE:}

\subsubsection{Theoretical and conceptual literature review}

The term NGO is a broad and ambiguous term. It covers a number of civil society organizations ranging from political action groups to sports clubs. Its clear definition still remains contested. However, it can be argued that all NGO's can be regarded as civil society organizations though not all civil society organizations are NGO's. The concept of NGO came into use in 1945 following the establishment of the United Nations Organizations which recognized the need to give a consultative role to organizations which were classified as neither 
government nor member states (Lekorwe, 2007:12). NGOs take different forms and play different roles in different continents, with the NGO sector being most developed in Latin America and parts of Asia. The roots of NGOs are different according to the geographical and historical context. They have recently been regarded as part of the "third sector" or not-for-profit organizations. Although there is contestation of the definition of an NGO, it is widely accepted that these are organizations which pursue activities to relieve the suffering, promote interests of the poor, protect the environment, provide basic social services, and undertake community development (Lekorwe, 2007:12).

\subsubsection{Emergence of Ngos in Ethiopia}

Modern civil associations began to emerge in Ethiopia during the 1930s as a factor of urbanization and economic development. A law meant to recognize and codify these groups was passed in 1960. Civil society entities in general, however, were slow to take root under the empire and then severely restricted during the Derg period (1974-91). During the last decade and a half of Emperor Haile Selassie's reign, professional groups such as the Chamber of Commerce and National Bar Association formed, played somewhat credible roles, and enjoyed relative autonomy. That autonomy completely evaporated under Mengistu's long reign of terror, however, and virtually all these organizations effectively became tools of the state or ceased operations entirely. Many of those remaining in existence lost credibility, professionalism, and, ultimately, much claim to legitimacy (Clark, 2000:4). National and international NGOs in Ethiopia began to appear around 1960, when neither the various self-help groups found in all levels of Ethiopian society nor the government was able to meet the growing demands of the population. The then current efforts of the emperor to "modernize" the national education system had resulted in a more widespread awareness that his government was failing to provide what people needed for advancement and development. NGOs began in a small way to help fill the perceived void (Clark, 2000:4).

\subsubsection{Roles of Non Governmental Organizations}

In general, NGOs are perceived to play valuable roles in both the developmental and democratization process of a country. The international network of civil society groups, lists five "essential roles" for civil societies (Eman, 2012:29):

1. Influencing public policy: this dimension consists of three sub-areas, namely roles in influencing the national budget process, human rights issues and social policy issues.

2. Holding state and private corporations accountable for their decisions and actions. Here NGO's sole in "monitoring, making transparent and if appropriate, speaking out against actions undertaken by government and the private sector in violations of their stated goals, objectives and tasks" has been significant.

3. Responding to social interests: this relates to the role of NGOs in taking up and voicing societal concerns, and their ability to function as "representatives" and "particulars" of their interests of communities.

4. Empowering citizens: enabling citizens, particularly the poor and the disadvantaged, to have more choice and to take more control over decisions that affect their lives through information and education, developing capacity for collective action, and building social capital.

5. Meeting societal needs: this concerns service delivery, promoting self-help initiatives, helping people to meet their pressing societal needs.

\subsubsection{NGO's and Primary Education}

In developing countries including Ethiopia, NGOs play a very important role in the development process. In subSaharan Africa, their contributions are particularly significant in supporting literacy, community schools, health education, early childhood care, skills training and other forms of learning, thus helping people to improve their living conditions. Although the activities of the foreign NGOs in the developing countries have received extensive treatment in the literature, the contributions of indigenous or local NGOs in socio-economic development have gone largely unnoticed. The fact is that there are hundreds of such NGOs making positive contributions within their respective countries, but are not known beyond their borders (Fielmna, N., \& Bandie, R., 2012:49). Local NGOs and their proximity to a community serve as a conduit through which resources from donor/international NGO supported programs can flow to the community (Yolande, Welmond and Wolf, 2002:33). NGOs also assist in creating or training school committees and/or parent-teacher associations (PTAs). Their study brought to light the common assumption held by donors and international NGOs that stronger local NGOs strengthen civil society; that supporting local NGOs' involvement in education will increase the relevance and sustainability of sector programs (Yolande, Welmond and Wolf, 2002:33).

\subsubsection{Conceptual Framework of the Research}

The researcher tried to review some literature and prepare conceptual framework of the study that appears as follows. 


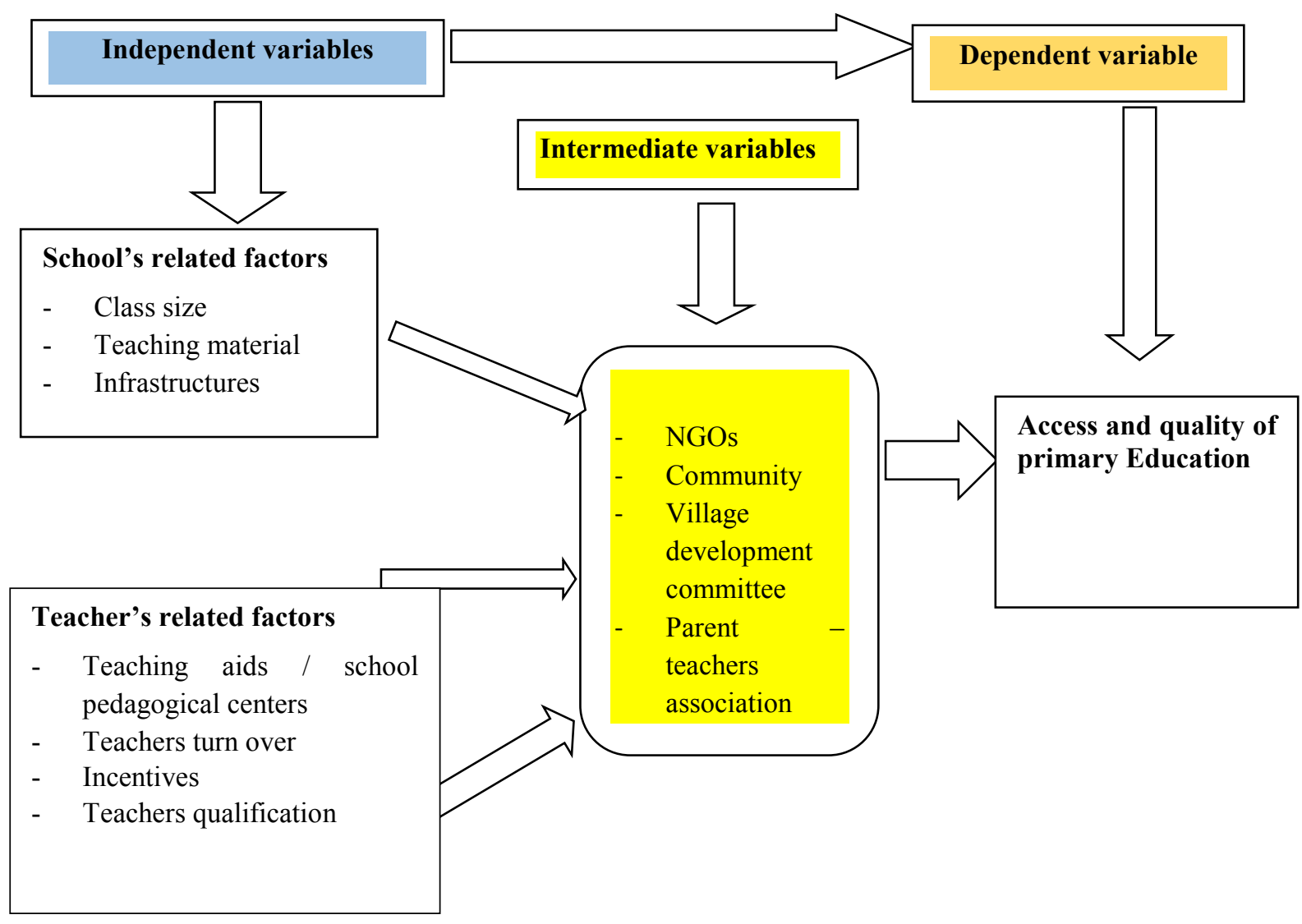

\section{Governmental related factors}

- Capacity at grassroots level

- Political commitment

- Participation

Source: Researcher own construction, 2018

\subsection{RESEARCH METHEODOLOGY}

The study adopted both qualitative and quantitative survey design as it aims at collecting information from respondents. Moreover, Multi stage sampling technique sampling technique was employed by researcher because believes that these sectors likely have sufficient information and exposure on the topic under study. Out of the total 10,632, respondents, 201 sample respondents were selected.

Thus, $\mathrm{n}_{1}=\mathrm{n}\left(\mathrm{N}_{1} / \mathrm{N}\right)$ and hence $\mathrm{n}_{1}=201(3,842 / 10,632)=73$.

$\mathrm{n}_{2}=\mathrm{n}\left(\mathrm{N}_{2} / \mathrm{N}\right)$ and hence $\mathrm{n}_{2}=201(1,500 / 10,632)=28$.

$\mathrm{n}_{3}=\mathrm{n}\left(\mathrm{N}_{3} / \mathrm{N}\right)$ and hence $\mathrm{n}_{3}=201(750 / 10,632)=14$.

$\mathrm{n}_{4}=\mathrm{n}\left(\mathrm{N}_{4} / \mathrm{N}\right)$ and hence $\mathrm{n}_{4}=201(1,536 / 10,632)=29$.

$\mathrm{n}_{5}=\mathrm{n}\left(\mathrm{N}_{5} / \mathrm{N}\right)$ and hence $\mathrm{n}_{5}=201(985 / 10,632)=19$.

$\mathrm{n}_{6}=\mathrm{n}\left(\mathrm{N}_{6} / \mathrm{N}\right)$ and hence $\mathrm{n}_{6}=201(2,019 / 10,632)=38$.

\subsection{DATA ANALYSIS AND DISCUSSION}

In conducting the study, 201 questionnaires were distributed out of which 201 were returned and answered. Therefore, the response rate was $100 \%$. 


\subsubsection{Enrollment of girls before project intervention}

Table 1: Response on reasons for low enrollment of girls before project intervention

\begin{tabular}{|c|c|c|c|c|c|c|c|c|c|c|}
\hline $\mathbf{S} / \mathbf{N}$ & Reason for low enrollment & $\mathbf{1}^{\mathrm{st}}$ & $2^{\text {nd }}$ & $3^{\text {rd }}$ & $4^{\text {th }}$ & $5^{\text {th }}$ & $6^{\text {th }}$ & $7^{\text {th }}$ & $8^{\text {th }}$ & $9^{\text {th }}$ \\
\hline 1 & $\begin{array}{l}\text { Low house hold income and inability to cover learning } \\
\text { materials costs }\end{array}$ & & & & 19 & 1 & 173 & |1 & 2 & 5 \\
\hline 2 & Long distance to school & 1 & & & 180 & & 19 & & & 1 \\
\hline 3 & $\begin{array}{l}\text { Low provision of education materials and text books from } \\
\text { school }\end{array}$ & & & & & 7 & 2 & 190 & 1 & 1 \\
\hline 4 & Cultural barriers like abduction, early marriage etc & 35 & 88 & 78 & & & & & & \\
\hline 5 & $\begin{array}{l}\text { Poor infrastructure and lack of necessary furniture and } \\
\text { equipment to accommodate children }\end{array}$ & & & & & 185 & & 10 & & 6 \\
\hline 6 & Low awareness of parents to send children to school & 45 & 70 & 86 & & & & & & \\
\hline 7 & Obligation of parents for child labor before school & 121 & 43 & 37 & & & & & & \\
\hline 8 & $\begin{array}{l}\text { Poor management of school by school leaders in terms of } \\
\text { facility and unwillingness to hire qualified teachers }\end{array}$ & & & & 1 & 1 & 6 & & 14 & 179 \\
\hline 9 & Shortage of well trained and qualified teachers & & & & & 7 & 1 & & 184 & 9 \\
\hline & Total & & & & & & & & & \\
\hline
\end{tabular}

Source: Field survey (2018)

As depicted in the above 'table 1', the respondents were provided with a list of items that were assumed to be the main causes for lower students' participation before the intervention of local NGOs. They then were asked to rank them by choosing them in terms of their seriousness from high to low. The result in the above 'table 2' revealed that the first three causes for lower students' participation identified by the respondents were obligation of parents for child labor before school, low awareness of parents to send children to school and cultural barriers like abduction, early marriage etc. It can be deduced from the above table that most of the causes for lower students' participation are related to family and community problems. Moreover, with respect to low awareness of parents to send children to school, Pearson Chi-square $X^{2}(4, N=201)=109.7835, P=0.0000$ (see appendix 5f) indicates that the low awareness of parents to send children to school shows statistically significant relationship with obligation of parents for child labor before school. This implies that as their awareness to send their children to school is low, they might force their children to work at home before school.

1.6.2. Analysis Of Likert Scale Questions

Table 2: Response on contribution of NGOs in creating access

\begin{tabular}{|c|c|c|c|c|c|c|c|}
\hline SN & Research questions on Access & & $\varpi \stackrel{0}{\omega}$ & $\ddot{\theta}$ & $\ddot{z} \equiv$ & $<\dot{00}$ & $\ddot{\infty} \doteq$ \\
\hline \multirow[b]{2}{*}{1} & \multirow{2}{*}{$\begin{array}{l}\text { The project equipped the school with } \\
\text { appropriate educational materials }\end{array}$} & Frequency & & 14 & & 18 & 169 \\
\hline & & Frequency $\%$ & & 6.97 & & 8.96 & 84.08 \\
\hline \multirow[b]{2}{*}{2} & \multirow{2}{*}{$\begin{array}{l}\text { The school was established with particular } \\
\text { emphasis to girls education }\end{array}$} & Frequency & & 14 & & & 187 \\
\hline & & Frequency $\%$ & & 6.97 & & & 93.03 \\
\hline \multirow[b]{2}{*}{3} & \multirow[t]{2}{*}{ The school arranges tutorial classes } & Frequency & & 14 & 6 & 32 & 149 \\
\hline & & Frequency $\%$ & & 6.97 & 2.99 & 15.92 & 74.13 \\
\hline \multirow{3}{*}{4} & \multirow{3}{*}{$\begin{array}{l}\text { Academic competition enhanced by providing } \\
\text { awards for competent students' Academic } \\
\text { competition enhanced by providing awards for } \\
\text { competent students }\end{array}$} & Frequency & & & & 37 & 164 \\
\hline & & Frequency $\%$ & & & & 18.41 & 81.59 \\
\hline & & & & & & & \\
\hline \multirow{3}{*}{5} & \multirow{3}{*}{$\begin{array}{l}\text { Different workshops are being organized with } \\
\text { the aim to encourage student participation and } \\
\text { enhance their skills }\end{array}$} & Frequency & & & & 23 & 178 \\
\hline & & Frequency $\%$ & & & & 11.44 & 88.56 \\
\hline & & & & & & & \\
\hline \multirow[b]{2}{*}{6} & \multirow{2}{*}{$\begin{array}{l}\text { Community awareness to send children to } \\
\text { school is created }\end{array}$} & Frequency & & & & 8 & 193 \\
\hline & & Frequency $\%$ & & & & 3.98 & 96.02 \\
\hline \multirow{3}{*}{7} & \multirow{3}{*}{$\begin{array}{l}\text { The local NGOs intervention has helped to } \\
\text { improve primary education and teaching- } \\
\text { learning process }\end{array}$} & Frequency & & & & 5 & 196 \\
\hline & & Frequency $\%$ & & & & 2.49 & 97.51 \\
\hline & & & & & & & \\
\hline
\end{tabular}

Source: Field survey (2018) 
1.6.3. NGOs in improving quality of education

Table 3: Responses on contribution of NGOs in improving quality of education

\begin{tabular}{|c|c|c|c|c|c|c|c|}
\hline SN & Research questions on Quality & & 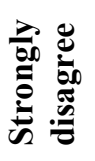 & 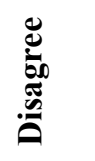 & 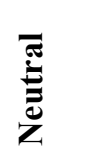 & 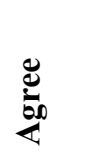 & 㐘 \\
\hline \multirow[b]{2}{*}{1} & \multirow{2}{*}{$\begin{array}{l}\text { Provision of different trainings or workshop to } \\
\text { upgrading teachers' professional careers }\end{array}$} & Frequency & & & 1 & 34 & 166 \\
\hline & & Frequency $\%$ & & & 0.50 & 16.92 & 82.59 \\
\hline \multirow[b]{2}{*}{2} & \multirow{2}{*}{$\begin{array}{l}\text { The qualities of education provision after the } \\
\text { project intervention }\end{array}$} & Frequency & & & & 29 & 172 \\
\hline & & Frequency $\%$ & & & & 14.43 & 85.57 \\
\hline \multirow{3}{*}{3} & \multirow{3}{*}{$\begin{array}{l}\text { Improvement seen with regard to construction } \\
\text { of standard library and pedagogical resource } \\
\text { center }\end{array}$} & Frequency & & & 28 & 27 & 146 \\
\hline & & Frequency $\%$ & & & 13.93 & 13.43 & 72.64 \\
\hline & & & & & & & \\
\hline \multirow[b]{2}{*}{4} & \multirow[t]{2}{*}{ Construction new schools and class rooms } & Frequency & & 38 & & 13 & 150 \\
\hline & & Frequency $\%$ & & 18.91 & & 6.47 & 74.63 \\
\hline \multirow[b]{2}{*}{5} & \multirow{2}{*}{$\begin{array}{l}\text { Supply of library, laboratory and classrooms } \\
\text { furniture and equipment }\end{array}$} & Frequency & & 28 & & & 173 \\
\hline & & Frequency $\%$ & & 13.93 & & & 86.07 \\
\hline \multirow[b]{2}{*}{6} & \multirow{2}{*}{$\begin{array}{l}\text { Supply of appropriate teaching and learning } \\
\text { aids and text books }\end{array}$} & Frequency & & & & 24 & 177 \\
\hline & & Frequency $\%$ & & & & 11.94 & 88.06 \\
\hline \multirow[b]{2}{*}{7} & \multirow{2}{*}{$\begin{array}{l}\text { Improvement in school expansion, upgrading } \\
\text { and maintenance or rehabilitation }\end{array}$} & Frequency & & & 70 & & 131 \\
\hline & & Frequency $\%$ & & & 34.83 & & 65.17 \\
\hline \multirow{3}{*}{8} & \multirow{3}{*}{$\begin{array}{l}\text { Teachers' residents' construction in order to } \\
\text { retain teachers with in school compound or } \\
\text { nearby }\end{array}$} & Frequency & & 128 & & & 73 \\
\hline & & Frequency $\%$ & & 63.68 & & & 36.32 \\
\hline & & & & & & & \\
\hline \multirow{2}{*}{9} & \multirow{2}{*}{$\begin{array}{l}\text { Helping girls and slow learners through the } \\
\text { arrangement of tutorial programs }\end{array}$} & Frequency & & & & 13 & 188 \\
\hline & & Frequency $\%$ & & & & 6.47 & 93.53 \\
\hline \multirow{3}{*}{10} & \multirow{3}{*}{$\begin{array}{l}\text { Construction of separate latrine for girl } \\
\text { students }\end{array}$} & Frequency & & & 10 & & 191 \\
\hline & & Frequency $\%$ & & & 4.98 & & 95.02 \\
\hline & & & & & & & \\
\hline
\end{tabular}

Source: Field survey (2018)

The above 'table 3' shows us, local NGOs give due attention on providing different trainings and workshops so as to upgrade teachers professional career. The data shows us almost $166(82.59 \%)$ of the respondents strongly agree with the provision of different trainings or workshop to upgrading teachers professional careers while the remaining $34(16.92 \%)$ respondents agree and the remaining $1(0.5 \%)$ respondent remained neutral on the issue of trainings/ workshop to upgrade teachers professional career respectively.

Research shows that teacher knowledge profoundly affects student achievement. Darling-Hammond says flatly that teachers who lack knowledge of content and/ or teaching strategies cannot offer their students adequate learning opportunities. In today's high stakes education climate, those students may then be penalized for example, held back or not allowed to graduate when, in fact, the problem is the system's failure to provide them with qualified teachers (Mc Robbie, 2000:3). In the quest for improved student outcomes, teachers' professional development and education have reentered the public debate as a means to improve teaching. Professional development, or teacher education, comes in many forms and at many points throughout teachers' careers. Professional development, if well implemented, is a potentially promising strategy for improving teaching, and ultimately student learning, and state governments can serve many functions in its provision (ibid). 
Table 4: Responses on NGOs contribution in ensuring equity

\begin{tabular}{|c|c|c|c|c|c|c|c|}
\hline SN & Research questions on Equity & & 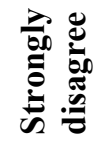 & 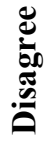 & 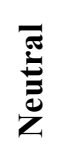 & 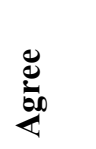 & 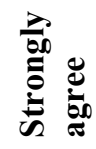 \\
\hline \multirow[b]{2}{*}{1} & \multirow{2}{*}{$\begin{array}{l}\text { The problems of school costs have been } \\
\text { avoided }\end{array}$} & Frequency & 29 & & & & 172 \\
\hline & & Frequency $\%$ & 14.43 & & & & 85.57 \\
\hline \multirow[b]{2}{*}{2} & \multirow{2}{*}{$\begin{array}{l}\text { Schools are made suitable or accessible for } \\
\text { children with disabilities }\end{array}$} & Frequency & & & & 31 & 170 \\
\hline & & Frequency $\%$ & & & & 15.42 & 84.58 \\
\hline \multirow[b]{2}{*}{3} & \multirow{2}{*}{$\begin{array}{l}\text { Educational materials and books are made } \\
\text { available for girls on the basis of one to one }\end{array}$} & Frequency & & & 5 & 18 & 178 \\
\hline & & Frequency $\%$ & & & 2.49 & 8.96 & 88.56 \\
\hline \multirow{3}{*}{4} & \multirow{3}{*}{$\begin{array}{l}\text { Female teachers are recruited and motivated } \\
\text { in schools to be seen as role model teachers } \\
\text { and attract girl students to school }\end{array}$} & Frequency & & & 18 & 40 & 143 \\
\hline & & Frequency $\%$ & & & 8.96 & 19.90 & 71.14 \\
\hline & & & & & & & \\
\hline \multirow[b]{2}{*}{5} & \multirow{2}{*}{$\begin{array}{l}\text { Award is available for better performing girl } \\
\text { students }\end{array}$} & Frequency & & & & 25 & 176 \\
\hline & & Frequency $\%$ & & & & 12.44 & 87.56 \\
\hline \multirow[b]{2}{*}{6} & \multirow{2}{*}{$\begin{array}{l}\text { Parents' awareness on importance of girl } \\
\text { education has been improved }\end{array}$} & Frequency & & & & 30 & 171 \\
\hline & & Frequency $\%$ & & & & 14.93 & 85.07 \\
\hline \multirow{3}{*}{7} & \multirow{3}{*}{$\begin{array}{l}\text { Girls counseling services and better support } \\
\text { have been given by establishing girls advisory } \\
\text { committees and school clubs }\end{array}$} & Frequency & & & 14 & 45 & 142 \\
\hline & & Frequency $\%$ & & & 6.97 & 22.39 & 70.65 \\
\hline & & & & & & & \\
\hline \multirow{3}{*}{8} & \multirow{3}{*}{$\begin{array}{l}\text { Linkages with the society and religious } \\
\text { institutions have been created to stimulate } \\
\text { them in girls education and decrease } \\
\text { repetition and drop out }\end{array}$} & Frequency & & & & 19 & 182 \\
\hline & & Frequency $\%$ & & & & 9.45 & 90.55 \\
\hline & & & & & & & \\
\hline
\end{tabular}

Source: Field survey (2018)

\subsubsection{Analysis Of Interview Of Local Ngos Representatives And Education Office Experts}

The interview questions were prepared and conducted with key informants were helpful in triangulating data obtained from students about the project intervention made by local NGOs. Mainly, the questions are designed for the representative of local NGOs/ Heads and education experts/ Managers from government offices based on the research objectives. Therefore, here under the researcher will try to present the response of respondents on the contribution of NGOs in creating access, improving quality and ensuring equity; participation and contribution of stakeholders; strategies on sustainability of the project and challenges faced during the project intervention as follows:

- Considerable number of NGOs selected rural areas for their intervention in order to fill the gap that the government can't reach. Because of the inaccessibility of the area, people were not privileged for access to education. The community lives in the area send their children to get access for education for more than 5 $\mathrm{km}$. In most cases, there were no school in the area before these projects intervention and therefore the education coverage was very low. On the other hand, very few NGOs intervene where government schools were providing services.

- The development support of any donor agency or NGO in any economic or social sector makes difference if it goes in line with the government's development policy. In this regard, educational officials at regional and District level were asked whether the selected local NGOs interventions are in line with the education policy of the country/region. Accordingly, they replied that as stated in the education and training policy, education as a very important factor to human development is of a high priority in the overall development endeavor of the government. Providing primary education is given the first priority. Regarding primary education, the government works to increase access, improve quality and ensure gender equity in educational provision and making it relevant to day-to-day activities of the society. Decentralized education management and community participation are also the emphasized areas of the policy. It also gives due respect for the involvement of non-governmental and private organizations in the provision of education for the citizens of the country.

- This sub-section deals with assessing the attempts made by the support of NGOs project to increase the 
participation of students in general and that of girls' in particular. Accordingly, there are some activities performed by the support of these projects in order to increase enrollment of students were building additional classrooms \& upgrading or maintenance of dilapidated buildings, construction of library, laboratory, pedagogical resource center, pit latrines and teachers residence, raising the awareness of the community to send their children to school, organizing tutorial programs to decrease repetition rate, organizing academic competition, question and answer competition, supply of educational materials including text books, supply of equipment and furniture, establish different school clubs and support in career upgrading of teachers. In addition to this, the intervention motivated teachers' in order to discharge their whole effort and ensure quality of education provision. In relation to girls' advisory committee, it is responsible for reporting to the Kebele Education and Training Management Board and Parents Teachers Association (PTA).

- Ensuring quality of education in project schools were one of the objectives of the selected local NGOs that have given emphasis and working on it for its realization. In this regard, as the researcher observed during the interview and focus group discussion, the project provided quality of education by building standard school buildings like class rooms, library, laboratory, pedagogical resource centers, improved pit latrines (for teachers, boys and girls separately), supplying educational materials (text books, reference materials, furniture, equipment etc), different awareness raising workshops for different stakeholders were conducted in order to promote children education in general and girls participation in particular, support teachers upgrading program, strengthening PTA by conducting different trainings on income generating schemes, disability, girls education, monitoring and evaluation of their projects, school leadership and community mobilization, supporting schools to generate their own income with in their compounds, providing for elder children vocational skills trainings, linking the school income generating scheme to district level micro and small enterprise development office, conducting different community conversations on different issues. This helped the NGOs to go deeper in to the grass root level and build trust from the community and ultimately ensured active community participation in their intervention.

- This sub-section deals with assessing the contribution made by the stakeholders for the implementation of the local NGOs education project. According to the information collected during interview and focus group discussion, the stakeholders contributed for the project by contributing labor during building constructions, supplying sand, soil, wood and other locally available materials and the like. In addition to this, stakeholders contributed money for purchasing land for school construction and expansion of the existing compounds. Above all, stakeholders contributed a lot for increasing participation of students and reducing drop out and repetition by dropout returning committee. In this regards, especially the community and government supervisors work day and night in order to raise the awareness of parents so as to send their children to school. Because of this, the number of students in the school increased and on contrary drop out decreased. The focus group discussions conducted with the community representatives and the interview made with local NGO representatives and education office experts and managers also confirmed that the participation of all stakeholders during project intervention played significant role in increasing enrollment of students in the project schools.

- In this regard, interview was conducted with the relevant NGOs representatives and education office experts. Most of the respondents agreed with the participation of stakeholders in project identification, planning (design), implementation, and monitoring and evaluation was very high. Whereas the remaining few respondents disagree with the above issue and responded minimum participation seen during the intervention especially in monitoring and evaluation parts. The issue is also raised during the focus group discussion and confirmed as it is there.

- It is known from the experience that the support of any donor agency or Non-Governmental Organization (NGO) in any development project does not last long. It phases out after it meet its target. Externally motivated projects frequently fail to sustain themselves when the initial support diminishes or are withdrawn. To mitigate this problem, the supporting (intervening) agency should design mechanisms that would maintain the continuity of the project activities after it withdraws its grant/support. In this regard, the representatives of local NGOs were asked about the strategies they designed in collaboration with different stakeholders to make the project sustainable when the project phases out. According to their response, orientations had been given since the commencement of the project's activity in the schools. The stakeholders were told that the project would not stay long with them and it would be the community and local government that maintain the continuity of the activities of the schools when the project withdraws its financial support/ phased out. During the project implementation, gradually, more of the project activities were handed over to the stakeholders in order to create smooth handing over of the project.

- The representatives of local NGOs were asked about problems they confronted with during project implementation. According to their response, the problems that the project faced for effective implementation of the project activities and achievement of the intended goals were lack of capacity at 
lower government bodies and grass-roots level to manage schools effectively. Because of this, it was difficult to get support from the grass root level as required. In addition to this, shortage of qualified teachers on market was also another challenge. In this regard, since their plan was to provide quality of education to the target area, it wasn't easy to allocate the right person on the right place. High turnover of educational personnel, head teachers and frequent dismissal of authorities from district to kebele level from their position after they have received the necessary training was another problem encountered by NGOs.

\subsection{CONCLUSION}

Based on the above major findings of the study, the following conclusions were drawn:

The participation of students in general and that of girls in particular in those districts was not promising before the intervention of the project indicating that many school age children lacked equitable access to primary schools where girls were more affected. In addition to this, the standard and availability of quality contributors were low which might have affected the quality of education provided in the schools.

The quality contributors improved the quality of education provision in the project schools. However, there are problems in relation to construction of additional classrooms and teachers residents in some of those sampled areas. Unless the intervention is made in this regards, their quality of education provision in the schools might be deteriorated.

The local NGOs experience in planning and implementing the development activities are encouraging. The attempt of the project in empowering the local community representatives to identify and prioritize their schools' problems, and making them plan, monitor and evaluate their project's activities by themselves. The awareness raising workshops the project conducted before the identification and prioritization of the project enabled the school management committee to develop independence and self-confidence in planning and implementing their project activities. Effective planning enabled the schools to utilize the available resources efficiently, and there is no unwise utilization and embezzlement of schools' resources. However, there are gaps in some NGOs in mobilizing and participating their stakeholders in monitoring and evaluation of their projects. Ultimately, this will decrease the sense of ownership creation from the community side and decline involvement of stakeholders in relation to school affairs.

Raising the awareness, providing sustainability training and preparing exit strategy document by concerned stakeholders in order to make the project's activities sustainable are encouraging. Different strategies designed to make the project sustainable after the NGOs support phased out. Most of the program components will sustain as it is. However, some activities like provision of vocational skills need to be strengthened further before the project phased out since the government can't take them as part of the school.

There are different challenges faced by local NGOs during the implementation of their project. To mention few critical ones, lower capacity of government officials at grass-roots level to support and manage the project intervention by NGOs, shortage of qualified teachers on market, staff turn over from government education office after taking orientation about the program, hindrance of new Civil Societies proclamation of 30:70 in shifting some stakeholders capacity building programs in to program components and discrepancy on intervention between plans versus achievements were another problems encountered by NGOs. On the other hand, education experts raised their challenges in relation to NGOs intervention like, not sending report on time, delay during implementation; NGOs confined themselves around cities and variation on plan versus achievement seen in relation to some NGOs. The above mentioned problems rose from NGOs and education offices were hindered the smooth implementation of the project. Unless they are solved, it will be difficult to achieve the predetermined objectives and benefit the poorest of poor group of the community.

\subsection{RECOMMENDATIONS}

Based on the findings of the study the following recommendations were forwarded:

1. The local NGO projects have succeeded in achieving its strategic objectives and supplementing the effort of the government in universalizing primary education. The initiative of the project to work with local government and community and strengthening community government partnership (including empowering them to implement and manage the project's activities) can be considered as significant input. Therefore, other NGOs and concerned government bodies should adapt the practice for similar interventions in the process of expanding educational opportunities for marginalized localities.

2. During the project intervention, NGOs gave priority at enrollment for girl students and in the meantime, conducting community conversations in sending girl children to school. Because of this, the number of girls' students increased dramatically in school. It is supported by different motivating factor in order to retain them in the school like academic competition and award provision for winner girls, provision of different educational materials, and construction of separate latrine for girl students and arrange tutorial classes for girls and the like. Therefore, these initiatives should be carried on in order to retain them in school and improve their result as well. Therefore, government and community should give due attention and carry on 
initiative started by these local NGOs and continue the assistance provision after the NGOs projects phased out.

3. There are considerable numbers of older children learning in primary schools opened by local NGOs. This shows that, in rural and remote areas there are also large number of older out of school children beyond the conventional school age without access to primary education. Therefore, NGOs should focus on rural and remote areas in order to address the poorest of poor children who lack access to education in the rural setting rather than confining themselves around cites. Hence, policy makers should study their situations and motivate them by increasing their administration costs in order to attract them to go to far and remote areas.

4. As the research reveals, more than $2 / 3^{\text {rd }}$ of the respondents have large family size with more than 6 family members. It has its own impact on quality of service provision especially in relation to social services. Therefore, if NGOs have a plan to intervene in such areas of having high density of population, they should integrate their program with of family planning as well in order to awaken the community so as to manage their family size.

5. The result of the research revealed that the first three causes for lower students' participation identified by the respondents were obligation of parents for child labor before school, low awareness of parents to send children to school and cultural barriers like abduction, early marriage etc. It can be deduced from the above table that most of the causes for lower students' participation are related to family and community problems. Therefore, they are a good indicator for a kinds of problems entertained by a community in relation to different interventions. So, NGOs should make their study in relation to reasons for low beneficiaries' participation before they directly intervened so as to alleviate the community problems in order to be successful in their project intervention.

6. Participatory Monitoring and Evaluation (PME) offers development organizations a host of opportunities for improving the performance of their programs and building the management capacity of local partners and stakeholders. While many local NGOs can evaluate their programs using outside "expert" approaches, few have the know-how and skills to employ PME approaches and fewer still are able to design and implement effective PME systems. In this regard, most of NGOs facilitate the ground to participate their stakeholders starting from project identification till monitoring and evaluation. According to the research finding, some NGOs don't engaged stakeholders in project identification and monitoring and evaluation stages. Therefore, they should give the floor for all stakeholders so as to participate in all levels of project cycle and ensure the sustainability of their efforts.

7. In regards to strategies designed before the project commencement in order to sustain the efforts made by local NGOs, the researcher believes most of them will sustain after the project phases out. But, the vocational skills program needs some more effort in order to be strengthened and ensured its sustainability. Because, vocational skill program is not part of government school. The government will not allocate budget for vocational skills provision in its schools. Therefore, school management committee and district education offices should work together to sustain the started good efforts of NGOs and ensure the benefit of those older children so as to generate their own income and continue their education without financial problems. In addition to this, girls' advisory committee also needs attention to secure the participation of girls as needed in the school. NGOs has made their own efforts and increased the number of girls' participation in the school. Therefore, the district education office and the community together should work so as to ensure better participation of girls in the school by motivating them to go to school and achieve better result in their academic endeavor than before.

8. According to the research findings, the problems that the project faced for effective implementation of the project activities and achievement of the intended goals were lack of capacity at lower government bodies and grass-roots level to manage schools effectively, shortage of qualified teachers on market, high turnover of educational personnel, head teachers and frequent dismissal of authorities from district to kebele level, overcrowded class rooms, new Civil Societies proclamation of 30:70, high expectation from community realized, delay on budget transfer, financial crisis and exercising new approach.

\subsection{REFERENCES}

Abera Argo. (2011). The Role of NGOs in Human Capital Development: the Case of USAID/World Learning/ Project in promoting Primary Education in Sidama Zone.

Amandla Development. (2010). NGOs, Education and Opportunity in South Africa: An Analysis of Macro and Industry and Capacity Needs. The Journal of International Social Research, 6(26), 9.

Angela, S. (2000). The World Bank New Discourse and the 1999 Education Sector Strategy. Education Resources Information Centre (ERIC). Retrieved from www.eric.ed.gov (October 30, 2010).

Cohen, A., Kulik, A., \& Chen-Lin, C. (2011). Educational Outcomes of Tutoring: A Meta- analysis of Findings. American Educational Research Journal. 19 (2), 237-248.

CRDA (2005a, April 14-25, 2005). “Training Program on Participatory Project Development”. Prepared and 
Conducted by Development Studies Associates. Addis Ababa.

Dessalegn Rahmato, Akalewold Bantirgu \& Yoseph Endeshaw, (2008). CSOs/NGOs in Ethiopia: Partners in Development and Good Governance. A Study Prepared for the Ad Hoc CSO/NGO Task Force on Creating an Enabling Environment for Civil Society. Retrieved January 6, 2015 from http://www.csos-NGOs-in Ethiopia Partnersi Development.pdf

Eman Mohammed. (2012). The Impact of the Charities and Societies Proclamation on Civil Society Organizations (CSOs). Unpublished Master's Thesis, Addis Ababa University, Addis Ababa, Ethiopia.

Fraser, A. (2013). A Critical examination of the role and impact of NGOs in the provision of housing for the poor of poor Addis Ababa: Application of a rights based on lens. Unpublished MA thesis, Massey University, Palmeerston, New Zealand.

Horton, D. (2003). Evaluating Capacity Development: Experiences from Research and Development Organizations Around the World. Ottawa: International Development Research Centre. Retrieved 27 November 2014 from: www.cta.int/pubs/isnar2/ECDbook(final).pdf

Ismail, M. (2012). Study on the Role of NGOs in Imparting Primary Education in Pakistan: Interdisciplinary Journal of Icontemporary research in business, 4(1). Retrieved November 27, 2014, from http://www. ijcrb.webs.com

Riedling, A. (2006). Learning to Learn: A Guide to Becoming Information Literate in the $21^{\text {st }}$ Century. 2nd edition. New York, N.Y.: Neal-Schuman Publishers.

Rifkin, S. (2003). A Framework Linking Community Empowerment and Health Equity: It is A Matter of CHOICE, Health Population Nutrition, 21 (3), 168-180.

Rocha, C., Menocal, A., and Sharma, B. (2008). Joint Evaluation of Citizens' Voice and Accountability: Synthesis Report. London: Overseas Development Institute for DFID.

Ryan, A., Jennings, J., \& White, J. (2007). BRAC Education Program. BEP 2004-2009, Mid- Term Review. Oslo: Norad. $\quad$ Retrieved $\quad 27 \quad$ November $\quad 2014$ from: www.niaslinc.dk/gateway_to_asia/nordic_webpublications/x506033235.pdf 